\title{
Sub-annual fluorescence measurements of coral skeleton: relationship between skeletal luminescence and terrestrial humic- like substances
}

\author{
Nikita Kaushal ${ }^{1}$ (D) Liudongqing Yang ${ }^{1,2} \cdot$ Jani T. I. Tanzil $^{2,3,4} \cdot$ Jen Nie Lee $^{5} \cdot$ \\ Nathalie F. Goodkin ${ }^{1,2,6} \cdot$ Patrick Martin ${ }^{1}$
}

Received: 13 April 2020/Accepted: 19 May 2020/Published online: 28 May 2020

(C) The Author(s) 2020

\begin{abstract}
Some massive coral core slices reveal luminescent bands under ultraviolet light, which have been attributed to terrestrial humic acids in the skeleton. Coral luminescence has therefore been used to reconstruct past climate and hydrological variability. However, it has remained unresolved how closely coral luminescence at sub-annual resolution is related to terrestrial humic acid concentrations. This study presents a solution-based fluorescence method to quantify terrestrial humic substances in less than $4 \mathrm{mg}$ of coral powder. The results show that in
\end{abstract}

Topic Editor Anastazia Banaszak

Nikita Kaushal and Liudongqing Yang have contributed equally to the work.

Electronic supplementary material The online version of this article (https://doi.org/10.1007/s00338-020-01959-x) contains supplementary material, which is available to authorized users.

\section{Nikita Kaushal \\ nkaushal@ntu.edu.sg \\ $\bowtie$ Patrick Martin \\ pmartin@ntu.edu.sg}

1 Asian School of the Environment, Nanyang Technological University, Singapore, Singapore

2 Earth Observatory of Singapore, Nanyang Technological University, Singapore, Singapore

3 St. John's Island National Marine Laboratory, National University of Singapore, Singapore, Singapore

4 Tropical Marine Science Institute, National University of Singapore, Singapore, Singapore

5 Faculty of Science and Marine Environment, Universiti Malaysia Terengganu, Kuala Nerus, Malaysia

6 Department of Earth and Planetary Sciences, American Museum of Natural History, New York, USA corals from Malaysia and Singapore, the luminescence green-to-blue ratio is correlated with skeletal concentrations of terrestrial humic substances $\left(R^{2}>0.40\right.$, $p<0.001)$ at two sites that are exposed to terrestrial dissolved organic matter from peatlands on Sumatra. In contrast, coral cores from two other sites located far from major terrestrial organic matter sources show lower greento-blue values and no convincing correlation with fluorescence intensity of terrestrial humic substances in the skeleton. Abiogenic aragonite precipitation experiments with both terrestrial and marine organic matter sources confirmed that terrestrial humic substances are readily incorporated into aragonite, but not fluorescent organic matter from marine sources. The results of this study suggest that in coral cores with high luminescence greento-blue ratios ( $>0.6)$ and large downcore variability (range of $\geq 0.05$ ), the green-to-blue ratio is strongly linked to variation in terrestrial humic substances. Coral cores therefore have the potential to reconstruct past variation in terrigenous dissolved organic carbon fluxes.

Keywords Fluorescent dissolved organic matter - Coral luminescence · Humic-like substances · EEM - Terrigenous dissolved organic matter

\section{Introduction}

Some aragonite skeletons of massive corals such as Porites spp. are important paleo-archives, as they record many environmental properties via changes in the skeletal chemistry during growth (Druffel 1997; Lough 2010). It has long been known that corals deposit sub-annual bands that luminesce under long-wavelength ultraviolet (UV) light, and these bands have been shown to contain humic 
acids of terrigenous origin (Boto and Isdale 1985; Susic and Boto 1989; Susic et al. 1991). Humic and fluvic acids, collectively termed 'humic-like substances' (HULIS), are highly fluorescent compounds formed during decomposition of soil organic matter, and are a characteristic component of terrigenous dissolved organic carbon (tDOC; Coble 2007). Past studies of HULIS extracted from coral skeletons showed that bands with bright luminescence had higher humic acid concentrations and higher HULIS fluorescence than adjacent 'dark' bands (Susic et al. 1991; Matthews et al. 1996). Subsequent studies showed that variation in luminescence intensity in coral cores correlates with historical records of river discharge and rainfall for corals growing near the Burdekin River on the Great Barrier Reef (Isdale 1984; Isdale et al. 1998, 2016; Lough et al. 2002; Lough 2007), and more recently with salinity around the Thai-Malay peninsula (Tanzil et al. 2016). This demonstrates that coral luminescence can be used as a proxy for climate and hydrological variables. However, HULIS fluorescence intensity, often acquired through parallel factor analysis (PARAFAC) of fluorescence excitation emission matrices (Murphy et al. 2013), is also a well-established measure of tDOC in coastal oceans (Walker et al. 2009; Yamashita et al. 2011; Osburn et al. 2016). This suggests that coral luminescence might also act as a proxy for past changes in tDOC concentration in coastal waters.

The flux of tDOC through freshwater systems to the oceans is an important process in the global carbon cycle (Regnier et al. 2013). Although it is known that tDOC may be remineralized through photodegradation and biodegradation processes (Moran et al. 2000; Hernes and Benner 2003; Cory and Kling 2018), our broader understanding of the dynamics and biogeochemical fate of tDOC in the oceans remains limited (Bianchi 2011; Cai 2011; Zigah et al. 2017). Accurate historical time series of tDOC fluxes are required to understand natural drivers and processes of tDOC fluxes, and to examine whether human activities have altered these fluxes. For example, long-term increases in tDOC fluxes have been observed across northern Europe and North America, likely due to changes in atmospheric deposition (Evans et al. 2005; Monteith et al. 2007). However, long time series of DOC have not been measured in most parts of the world. Southeast Asia is thought to account for around $10 \%$ of the global land-to-sea tDOC flux because of the abundance of carbon-rich peatlands in the region (Alkhatib et al. 2007; Baum et al. 2007; Moore et al. 2011). These peatlands have been subject to extensive anthropogenic disturbances and land-use changes over the past decades (Miettinen et al. 2016) that have likely increased tDOC fluxes to the sea (Moore et al. 2013). HULIS fluorescence has already been shown to trace tDOC in Southeast Asian coastal waters (Harun et al. 2016; Zhou et al. 2019; Gandois et al. 2020). Moreover, because tDOC is also highly light absorbent, it reduces the depth of light penetration (Foden et al. 2008; Aksnes et al. 2009). The dynamics and possible long-term trends of tDOC in tropical seas therefore have important implications for the health of benthic habitats such as coral reefs. However, both light availability and the optical properties of dissolved organic matter have been comparatively little studied in coral reef environments (Tedetti et al. 2011; Edmunds et al. 2018). In the absence of historical measurements of riverine and coastal organic matter concentrations, proxy measurements provide the only way to reconstruct past tDOC fluxes in regions such as Southeast Asia.

However, to test the potential for luminescent bands in corals as a proxy for tDOC in coastal waters, more work is required to understand the relationship between coral skeletal luminescence and the concentration and types of humic substances in the skeleton. Most reported measurements of coral luminescence are from nearshore corals that are regularly exposed to terrestrial input delivered by rivers (Isdale 1984; Isdale et al. 1998, 2016; Lough et al. 2002; Lough 2007; Tanzil et al. 2016). But luminescent bands are also found in corals growing in offshore environments where tDOC inputs are minimal (Tudhope et al. 1996). This raises questions about whether other factors also influence luminescence intensity, such as variation in coral skeletal architecture (Barnes and Taylor 2005). This effect can be overcome if coral luminescence is expressed as a spectral ratio of green-to-blue luminescence (Grove et al. 2010), which normalizes for the effects of skeletal density and architecture. Fluorescent organic matter, including humic substances, are also produced in the marine environment by phytoplankton and heterotrophic microbes (Osburn et al. 2019), and it has been speculated that these marine fluorophores could also be incorporated into coral skeletons and contribute to luminescent banding (Tudhope et al. 1996). Further work is thus required to test whether variation in luminescence intensity at sub-annual timescales is directly related to variation in the concentration of terrestrial HULIS in the coral skeleton, and whether other types of fluorophores from natural dissolved organic matter can become incorporated into coral aragonite.

To investigate whether coral luminescence has potential as a proxy for terrigenous dissolved organic carbon (tDOC), we developed a method to measure terrestrial HULIS fluorescence in dissolved coral and abiogenic aragonite samples using solution-based fluorescence excitation emission matrix (EEM) spectroscopy, thus eliminating any confounding influence of skeletal architecture. We show that abiogenically precipitated aragonite incorporates terrestrial HULIS fluorophores roughly in the same proportion to their fluorescence intensity in the original 
solution, and with spectra showing similar features to coral samples. In contrast, abiogenically precipitated aragonite incorporates marine humic substances in much lower proportion to their fluorescence intensity in solution. We then show that the intensity of terrestrial HULIS fluorescence is very closely related to seasonal variation in luminescence intensity in multi-year time series of Porites spp. coral cores from two of four measured sites around peninsular Malaysia and Singapore. Our data show that in sites under the seasonal influence of tDOC-rich water masses, the variation in luminescence intensity at sub-annual timescales in the coral cores is largely driven by the incorporation of terrestrial HULIS, suggesting that coral cores may hold the potential to reconstruct past variation in tDOC fluxes.

\section{Materials and methods}

\section{Study sites}

Four cores from massive Porites spp. corals were collected from Kusu Island (Singapore, hereafter Kusu), Port Dickson (Malaysia), Pulau Tioman (Malaysia, hereafter Tioman), and Pulau Redang (Malaysia, hereafter Redang) (Fig. 1; Table 1). Port Dickson is located in the Malacca Strait on the west coast of Malaysia, Tioman and Redang are located in the South China Sea on the east coast of Malaysia, and Kusu is located in the Singapore Strait south of Singapore. These sites occur within $5^{\circ}$ latitude and longitude of each other and are therefore exposed to a similar monsoonal climate (Lau and Yang 1997; Wong et al. 2009), but differ substantially in their proximity to tropical peatlands (Fig. 1). Port Dickson and Singapore are both located close to the east coast of Sumatra, which is home to some of the largest deposits of tropical peatlands in Southeast Asia (Page et al. 2011; Dommain et al. 2014). Peatlands are considered to be the modern analogues for past coal-forming environments and are characterized by swamp forests in which woody plant material only partially decomposes in a water-logged environment (Hedges et al. 1985). Peat in Southeast Asia appears to be particularly rich in complex polyphenolic compounds (Yule et al. 2018), and these peatlands are drained by rivers with extremely high concentrations (up to $5000 \mu \mathrm{mol}^{-1}$ ) of humic acid-rich DOC (Alkhatib et al. 2007; Martin et al. 2018). Tioman and Redang are located offshore of the east coast of Malaysia, far from any major peatland deposits (Fig. 1). Seasonally reversing monsoon winds alter the strength of ocean currents in this region (Gordon et al. 2003). During the summer monsoon, water in the Karimata Strait flows northward while the circulation in the Malacca Strait stagnates or flows southward, resulting in eastward current flow bringing water from the Sumatran coast into Singapore. During the winter monsoon, these currents reverse and water from the open South China Sea flows southward and westward into Singapore and northward through the Malacca Strait (van Maren and Gerritsen 2012; Rizal et al. 2012; Tanzil et al. 2019). Since peatlands are one of the most significant sources of tDOC to Southeast Asian coastal waters (Alkhatib et al. 2007; Baum et al. 2007; Moore et al. 2011; Wit et al. 2018), the seasonally
Fig. 1 Map shows distribution of peatlands and the locations of coral collection sites. Port Dickson; Kusu; Tioman; Redang. Figure modified from Dommain et al. (2014)

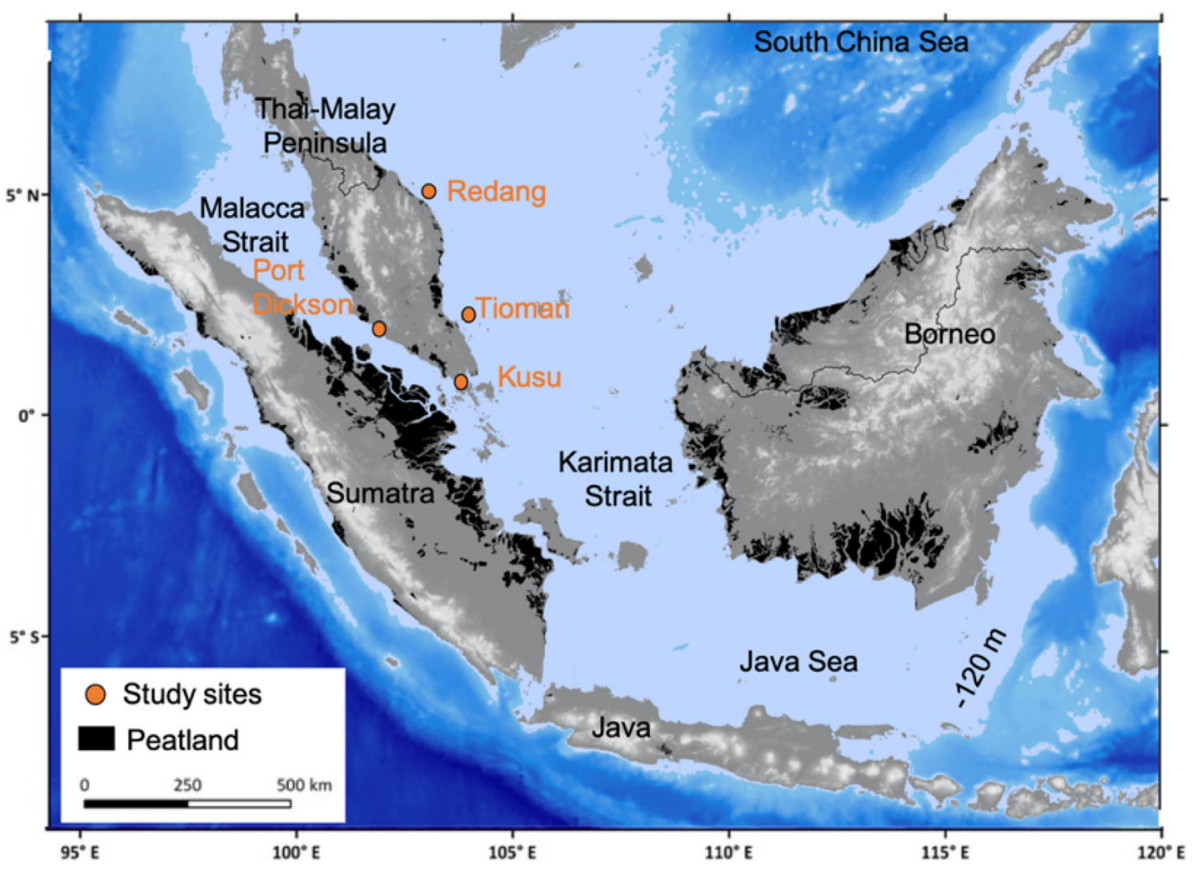


Table 1 Details of study sites

\begin{tabular}{lllll}
\hline Location, country & Latitude $\left({ }^{\circ} \mathrm{N}\right)$ & Longitude $\left({ }^{\circ} \mathrm{E}\right)$ & Type of fringing reef & Sampling date \\
\hline Port Dickson, Malaysia & 2.416 & 101.853 & Onshore & 12 Oct 2015 \\
Kusu Island, Singapore & 1.226 & 103.860 & Nearshore island & 15 Apr 2016 \\
Pulau Redang, Malaysia & 5.754 & 104.098 & Offshore island & 3 Jul 2011 \\
Pulau Tioman, Malaysia & 2.911 & 103.029 & Offshore island & 10 Apr 2011 \\
\hline
\end{tabular}

reversing currents are likely to result in high and seasonally variable tDOC concentrations in Singapore and Port Dickson, but not in Tioman or Redang.

\section{Coral collection and subsampling}

All cores were collected from depths of 2-3 $\mathrm{m}$ at mid-tide within the well-mixed upper water column. The cores were taken from the main growth axis of coral colonies measuring $0.5-2 \mathrm{~m}$ in diameter using a pneumatic drill fitted with a $5 \mathrm{~cm}$ diameter, $50 \mathrm{~cm}$ length diamond bit core barrel. Slices $(\sim 0.7 \mathrm{~cm}$ thick) were cut from coral cores and cleaned for $48 \mathrm{~h}$ in a 1:4 mix of commercially available household bleach solution $(\mathrm{NaOCl}, 3-7 \%$ reactive chlorine), and sonicated in deionized water for a total of $30 \mathrm{~min}$ (water changed every $10 \mathrm{~min}$ ). Treatment with the bleach solution removes contaminants and significantly increases the luminescence intensities (Nagtegaal et al. 2012). A detailed analysis of the density and luminescent banding patterns, and age models of the coral cores are described in Tanzil et al. 2016. For this study, we selected one section of $6-8 \mathrm{~cm}$ length from each core, corresponding to 4-5 yr of coral growth. For the Kusu coral core, an additional $8 \mathrm{~cm}$ long section that includes the 1998 El Niño event (when a major drought occurred in Southeast Asia) was analysed. Samples for fluorescence measurements were drilled from along the main growth axis using a $0.8 \mathrm{~mm}$ fixed drill, a $2 \mathrm{~mm}$ trench width and depth, and a sampling resolution of $3 \mathrm{~mm}$, which corresponds to 2-4 months of growth. Drilled powder samples were stored in microcentrifuge tubes until dissolution and further analysis.

\section{Standard preparation and method development}

A short coral section collected from Kusu, Singapore, was used to prepare a homogenous powder standard to develop a protocol for fluorescence measurements. The Kusu coral core was chosen because it has high luminescence intensity that is strongly correlated with variation in salinity (Tanzil et al. 2016), suggesting that this coral would contain readily measurable quantities of terrestrial HULIS to facilitate fluorescence method development. The coral skeleton $\left(\mathrm{CaCO}_{3}\right)$ was ground using a mortar and pestle and passed through a $250 \mu \mathrm{m}$ sieve. Aliquots $(1-5 \mathrm{mg})$ of coral powder were dissolved for fluorescence analysis as described below to test whether solution $\mathrm{pH}$ affected measured fluorescence intensity, and to verify that HULIS fluorescence intensity was linearly dependent on concentration. A previous study of coral skeletal fluorescence (Matthews et al. 1996) had identified the humic acid peak in corals at ex/em 340/450, which was already well documented as typical of humic acid in marine dissolved organic matter measured in coastal waters (Harun et al. 2016; Zhou et al. 2019; Gandois et al. 2020). Based on this prior study, and the measured spectra in our standard, we quantified terrestrial HULIS in this standard for the purpose of methods development as the mean fluorescence intensity at excitation 340-345 and emission 434-442.'

To test the effect of solution $\mathrm{pH}$ on fluorescence intensity, the coral powder was dissolved in $50 \mu \mathrm{l}$ of $2 \mathrm{M} \mathrm{HCl}$, diluted with deionized water (Elga, $18.2 \mathrm{M} \Omega \mathrm{cm}^{-1}$ ), and solution $\mathrm{pH}$ adjusted between 0 and 7 by addition of $2 \mathrm{M}$ $\mathrm{NaOH}$. Solution $\mathrm{pH}$ was measured using indicator paper. The total solution volume was maintained at $200 \mu \mathrm{l}$ by adjusting the volume of deionized water.

A further experiment was then carried out to verify that the HULIS fluorescence intensity is linearly related to fluorophore concentration. This was done by varying the mass of coral standard from 1.5 to $5.0 \mathrm{mg}$, and dissolving as above, with solution $\mathrm{pH}$ adjusted to above 2 and below 7. A purification step such as solid-phase extraction (Matthews et al. 1996) was not carried out, so as not to lose any fraction of the skeletal organic matter.

\section{Fluorescence measurements}

For aragonite powder sample analysis after the initial method development experiments, $2-2.5 \mathrm{mg}$ of sample was dissolved as described above, and the solution adjusted to $\mathrm{pH}$ between 2 and 7. Excitation emission matrix (EEM) spectra were acquired using a Horiba Scientific FluoroMax-4 spectrofluorometer with an integration time of $0.1 \mathrm{~s}$ across excitation $240-500$ and emission $300-600 \mathrm{~nm}$, and using a reduced-volume cuvette with $250 \mu$ capacity, and width and length of $3 \mathrm{~mm}$. During initial method development with the Kusu coral standard, $2 \mathrm{~nm}$ bandwidths and $2 \mathrm{~nm}$ increments were used for both excitation and emission. For subsequent sample measurements, $5 \mathrm{~nm}$ bandwidths with excitation increments of $5 \mathrm{~nm}$ and 
emission increments of $2 \mathrm{~nm}$ were used. Manufacturersupplied wavelength corrections were applied, and all measurements normalized to the reference detector $(\mathrm{S} 1 \mathrm{c} /$ $\mathrm{R} 1 \mathrm{c}$ mode i.e. the ratio of corrected signal to corrected reference mode). Data were then normalized to the Raman peak area of pure water (Lawaetz and Stedmon 2009) and are expressed in Raman units (RU). Inner-filter effects were negligible and no correction was applied: the typical absorbance values were $\leq 0.020$ absorbance units for the coral standard powder measured in a $1 \mathrm{~cm}$ cuvette for the wavelength range of interest $(330-600 \mathrm{~nm})$. All sample measurements were blank-subtracted by measuring fluorescence of an identical solution matrix to samples, but excluding $\mathrm{CaCO}_{3}$ powder (Fig. S1). The overall analytical precision was assessed using replicate analysis of the Kusu standard powder, which amounted to $\pm 0.8 \%$ relative standard deviation.

\section{Luminescence measurements}

Cleaned coral sections were photographed under ultraviolet (UV) light (350-450 nm) using spectral line scanning (SLS) on an Avaatech XRF core scanner (Grove et al. 2010; Tanzil et al. 2016) prior to drilling sample powders. The system records luminescence emission using a Line Scan camera, i.e. the light source and the camera progress down the coral slice as a single-unit scanning multiple lines that are stitched together to produce a continuous core image. Incoming light passing through the camera lens is split into three wavelength ranges (red, green and blue) by a dichroic RGB beam splitter prism and recorded by separate sensors. The luminescence green-to-blue measurement (Grove et al. 2010) for each coral sample was obtained along the main growth axis for a 2-mmwide track at a resolution of 143 pixels $\mathrm{cm}^{-1}$. The measurements were made at the excitation wavelength of $365 \mathrm{~nm}$ and emission wavelength ranges of blue $(425-475 \mathrm{~nm})$ and green $(525-575 \mathrm{~nm})$. Images of coral luminescence of each core section are shown in Fig. S2.

\section{Peak alignment}

Since luminescence measurements are made at a much higher resolution to fluorescence measurements, it is necessary to match the peak in luminescence with the peak in fluorescence, giving one value of luminescence green-toblue ratio for every fluorescence measurement. To do this, we performed an initial correlation analysis between luminescence and fluorescence measurements using three peak regions in the fluorescence EEM identified by a previous study of coral skeletal fluorescence (Matthews et al. 1996), and by PARAFAC analysis of peat-draining river and coastal waters from Southeast Asia (Zhou et al. 2019). For the purposes of this correlation, we used the mean fluorescence intensity at ex/em 340-345/434-442 nm (terrestrial HULIS; Matthews et al. 1996; Zhou et al. 2019), ex/em 310/390 nm (marine humic substances; Zhou et al. 2019), and ex/em 460/540 nm (commercial humic acid standards as measured by Matthews et al. (1996). We found that the correlation for the Kusu and Port Dickson cores was highest with the terrestrial HULIS fluorescence peak, while for the Redang and Tioman cores, the correlation was highest with the fluorescence at longer ex/em wavelengths shown by Aldrich and Fluka humic acids (Table 2). The luminescence green-to-blue time series was therefore aligned with the fluorescence time series for each core based on these correlations, using Analyseries 2.0 (Paillard et al. 1996), and then used for further analysis.

\section{Abiogenic aragonite precipitation experiments}

Abiogenic aragonite was precipitated from solutions containing peatland-draining river water, DOC generated by a marine plankton culture, and coastal seawater. Peatlanddraining river water was collected from the Maludam River, Sarawak, in August 2019, filtered through Whatman Polycap $0.8 / 0.2 \mu \mathrm{m}$ filters, shipped to Singapore in acid-cleaned HDPE carboys, and stored at $+4{ }^{\circ} \mathrm{C}$ until further use. This water sample is referred to hereafter as the peatland river water. The Maludam is a blackwater river, i.e. a typically slow-moving river that drains swamplands and is rich in dissolved humic substances, imparting the dark colour to the river water. The Maludam river drains a peat swamp forest that is protected as a national park, with DOC concentrations typically ranging from 3000 to $4000 \mu \mathrm{mol}^{-1}$ (Müller et al. 2016; Martin et al. 2018). Additional experiments were conducted with Maludam water that had been partially photodegraded by exposing it to natural sunlight in Singapore for $\sim 3$ months in 250-ml quartz bottles. This water is referred to hereafter as the photodegraded peatland river water in this study. The bottles were partially filled leaving a headspace of around $50 \mathrm{ml}$ and were periodically opened to allow aeration. The DOC concentration decreased from 3070 to $1674 \mu \mathrm{mol} 1^{-1}$ after 3 months of photodegradation.

To generate DOC of purely marine origin, enrichment cultures of field-collected phytoplankton were grown in the laboratory, following the experimental design of (Osburn et al. 2019). A natural phytoplankton assemblage was collected using a plankton net $(20 \mu \mathrm{m})$ at Kusu (Singapore) in November 2019. This was added to artificial sea water made from Red Sea salts amended with $f / 2$ growth medium (Guillard and Ryther 1962) in $175 \mathrm{~cm}$ polycarbonate culture flasks. The inoculated bottles and seawater controls (medium without cells) were kept on a shaker table for 20 days on a $12: 12$ light:dark cycle at $24{ }^{\circ} \mathrm{C}$. The inoculated bottles and controls were then placed in permanent dark conditions for 25 days to allow partial degradation 
Table 2 Correlation analysis ( $\mathrm{R}$ values) of luminescence green-toblue ratios of the five coral sections versus specific peaks identified in the fluorescence EEM-based on previously published literature
(Matthews et al. 1996; Zhou et al. 2019). Bold indicates the highest correlation value between luminescence green-to-blue ratios and the different fluorescence regions for five coral sections

\begin{tabular}{llll}
\hline Possible source/class of compound & Terrestrial HULIS & Aldrich and Fluka humic acids & Marine-like \\
\hline ex/em & $340-345 / 434-442$ & $460 / 540$ & $310 / 390$ \\
Kusu & $\mathbf{0 . 8 2}$ & 0.64 & 0.14 \\
Kusu (drought) & $\mathbf{0 . 7 7}$ & 0.75 & 0.56 \\
Port Dickson & $\mathbf{0 . 7 2}$ & 0.69 & 0.65 \\
Redang & 0.34 & $\mathbf{0 . 7 4}$ & 0.47 \\
Tioman & -0.33 & $\mathbf{0 . 6 1}$ & -0.62 \\
\hline
\end{tabular}

and reprocessing of the DOC by heterotrophic microbes. The DOC increased from 170 to $277 \mu$ mol $1^{-1}$. Samples were filtered through $0.2 \mu \mathrm{m}$ Supor polyethersulfone filters and stored at $+4{ }^{\circ} \mathrm{C}$ until further use. This water sample is referred to hereafter as the marine plankton culture water.

Natural seawater samples were collected monthly at $5 \mathrm{~m}$ depth from June, 2019 to January, 2020 at Kusu (Singapore) as part of a biogeochemical time series program. Water was immediately filtered through a $0.2 \mu \mathrm{m}$ pore-size Supor polyethersulfone filter using a peristaltic pump, returned to the laboratory, and stored at $+4{ }^{\circ} \mathrm{C}$ until further use. The sampling period covers the southwest monsoon when salinity is lowest and currents deliver tDOCrich water from off Sumatra to the Singapore Strait and the northeast monsoon, when currents deliver water from the open South China Sea (van Maren and Gerritsen 2012; Tanzil et al. 2019). The Kusu water samples gave an average DOC concentration of $81 \mu \mathrm{mol} 1^{-1}$ from June, 2018 to September, 2018 and an average concentration of $74 \mu \mathrm{mol} 1^{-1}$ from November, 2018 to April, 2019.

Aragonite was precipitated using a simplified version of the method of Gaetani and Cohen (2006). Briefly, $30 \mathrm{ml}$ of filtered sample water (Kusu seawater, plankton culture medium, or aliquots of Maludam river water in artificial seawater) was placed in a glass bottle with a magnetic stir plate at $100-150 \mathrm{rpm}$. A solution of $0.04 \mathrm{M} \mathrm{Na}_{2} \mathrm{CO}_{3}$ was then added at a rate of $100 \mu \mathrm{l}$ every $10 \mathrm{~s}$ for $15 \mathrm{~min}$. The sample was left on the stir plate overnight, and the precipitated aragonite powder collected on a $0.45 \mu \mathrm{m}$ cellulose acetate filter. This yielded around $10 \mathrm{mg}$ of aragonite powder per sample. For aragonite precipitation from Maludam water, artificial seawater was made from Sigma sea salts (S9883) and $30 \mathrm{ml} 18.2 \mathrm{M} \Omega \mathrm{cm}^{-1}$ deionized water, amended with $0.79 \mathrm{ml}$ river water and the addition of $10 \mathrm{ml}$ of $0.04 \mathrm{M} \mathrm{Na}_{2} \mathrm{CO}_{3}$ to give 40 times dilution and approximate the DOC of $75 \mu \mathrm{mol} 1^{-1}$ typically measured at Kusu.

Fluorescence spectra of aragonite samples were measured in the same way as coral powder samples. Fluorescence spectra of the solutions from which the aragonite was precipitated were measured before starting the precipitation experiments, using the same cuvette and fluorometer settings as for coral and abiogenic aragonite sample measurements, with $200 \mu \mathrm{l}$ of sample. For water samples, blank fluorescence spectra were measured with pure deionized water. The absorbance values for the peatland river water and marine plankton water were 0.015 and 0.047 in a $1-\mathrm{cm}$ cuvette in the wavelength range of interest; because fluorescence was measured in a cuvette with 3-mm length and width, inner-filter effect corrections were not applied.

\section{Results}

\section{Fluorescence measurements of dissolved coral skeleton}

Representative EEM spectra for each of the coral cores from Kusu, Port Dickson, Redang and Tioman are shown in Fig. 2. The spectra differ in their absolute intensities but show a very similar spectral shape, consisting primarily of a prominent feature in the traditional terrestrial humic-like region of ex/em 300-420/400-550 nm (Chen et al. 2003; Coble 2007), indicating the presence of terrestrial humiclike substances (HULIS) in the coral skeleton. Additional peaks observed at ex/em 270/320 nm (Fig. 2) are typically attributed to protein-like species such as tryptophan and tyrosine (Coble 1996; Matthews et al. 1996; Tedetti et al. 2011). The Kusu and Port Dickson cores show higher intensity HULIS fluorescence than the Tioman and Redang cores.

HULIS solubility is typically $\mathrm{pH}$-dependent, and fluorescence intensity can be reduced at low $\mathrm{pH}$ (Thurman and Malcolm 1981). An acidic $\mathrm{pH}$ cannot be avoided for this method since the coral skeleton has to be dissolved, but results in Fig. 3a show that as long as the final sample solution has a pH between 2 and 7 , the fluorescence intensity is not $\mathrm{pH}$-dependent. Below $\mathrm{pH} 2$, terrestrial HULIS is strongly reduced. Above $\mathrm{pH} 7$, precipitates (most 
likely of $\mathrm{CaCl}_{2}$ ) are rapidly formed. Large changes in solution $\mathrm{pH}$ are also best avoided because of the danger of fragmenting humic acid molecules (Green and Blough 1994). After $\mathrm{pH}$ adjustment to $>2.0$, the terrestrial HULIS fluorescence intensity in coral skeletons is a linear function of concentration, up to $4.0 \mathrm{mg}$ of coral per $200 \mu \mathrm{l}$ solution (Fig. 3b).

\section{Fluorophore incorporation in abiogenic aragonite}

Abiogenic aragonite precipitation experiments allow us to examine the range of fluorophores from natural DOC that might become incorporated into the coral skeleton during the calcification process. Comparing fluorescence spectra of initial water samples with the spectra of the aragonite that precipitates allows us to test whether aragonite selectively incorporates just terrestrial HULIS or whether a wide range of naturally occurring fluorescent DOC can be incorporated.

Figure $4 \mathrm{a}-\mathrm{c}$ show the fluorescence intensity at excitation $365 \mathrm{~nm}$ (typical of coral luminescence measurements
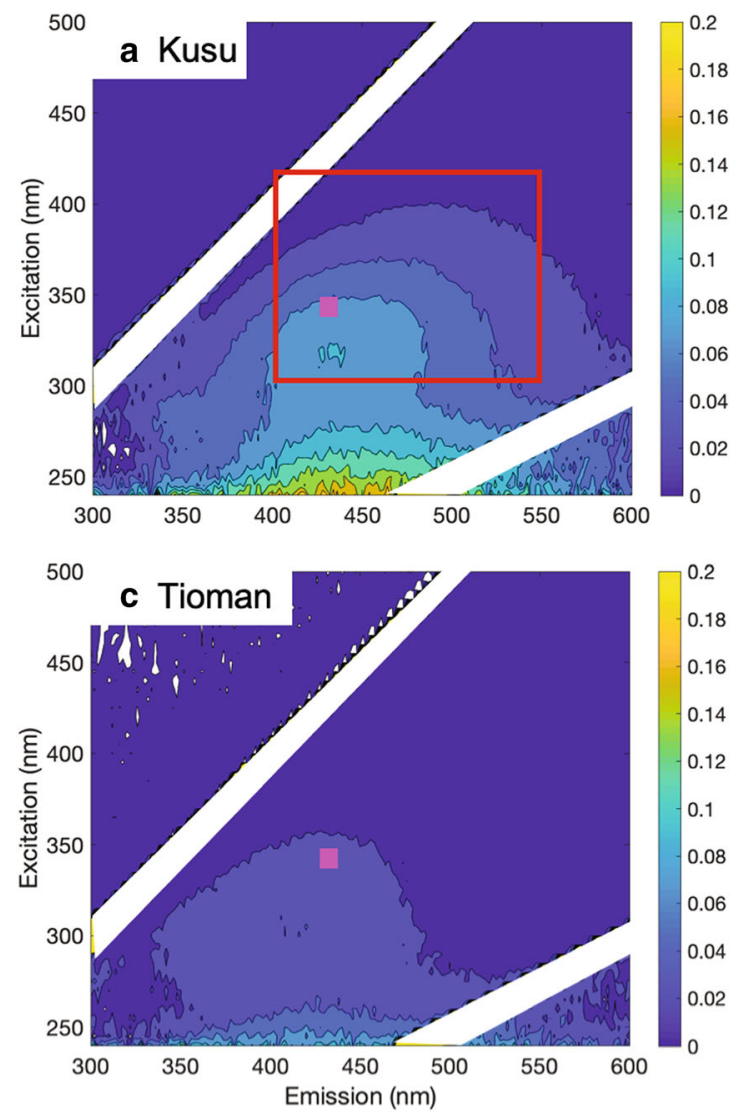

Fig. 2 Representative Excitation emission matrix (EEM) spectra for coral cores from a Kusu; b Port Dickson; c Tioman; and d Redang. Rayleigh scatter bands are masked. The large rectangle in (a) indicates the humic-like substance (HULIS) region described by Coble 2007 as ex/em 300-420/400-550 $\mathrm{nm}$. The solid pink rectangle in all the and within the range for terrestrial HULIS fluorescence) for the peatland river water, the photodegraded peatland river water, the marine plankton culture water, and for the aragonite precipitated from these waters. The peatland river water and resulting aragonite samples show peak fluorescence at longer wavelength values of ex/em $365 / 470 \mathrm{~nm}$, also after partial photodegradation, while the marine plankton culture water sample peaks at shorter wavelength values of $365 / 420 \mathrm{~nm}$. Within these regions, the aragonite precipitated from peatland river water has twice the fluorescence intensity of the water sample, even after photodegradation. In contrast, the aragonite precipitated from the marine plankton culture water has less than a quarter the intensity of the initial water. This clearly points to preferential incorporation of terrestrial fluorophores into aragonite.

Natural seawater samples collected at Kusu showed high fluorescence in the HULIS region at ex/em 340-345/ 434-442 nm during the southwest monsoon (June-August), but decreasing thereafter. Abiogenic aragonite precipitated from these waters incorporated HULIS
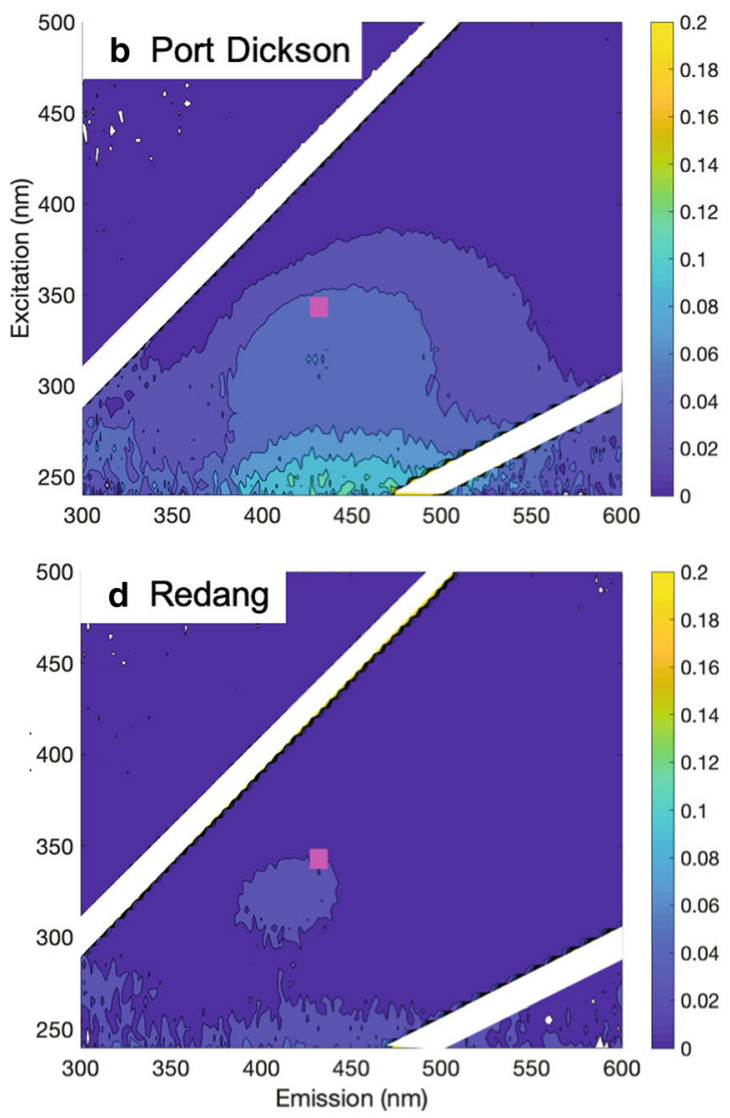

panels indicates the region used to quantify terrestrial HULIS for method development in this study (ex/em 340-345/434-442 nm). Fluorescence intensity in Raman Units (RU) is indicated by colour bars. Kusu and Port Dickson cores show higher intensity fluorescence compared to Tioman and Redang 

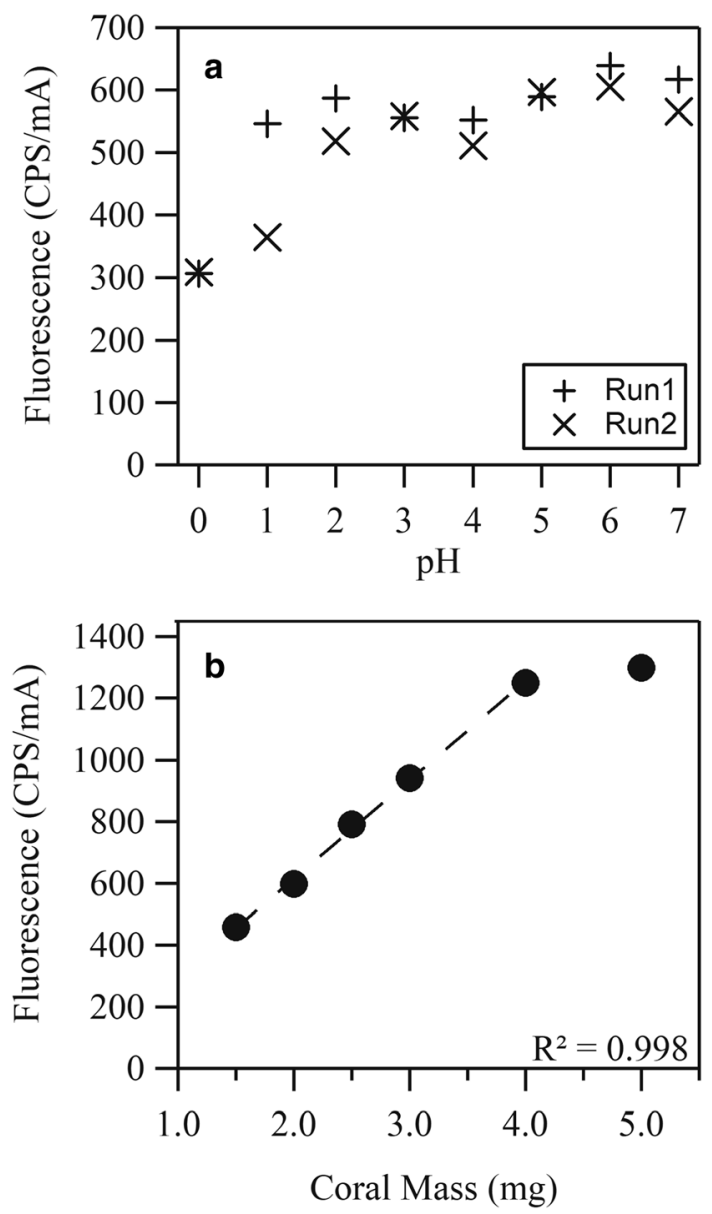

Fig. 3 a Florescence intensity of the coral standard powder terrestrial HULIS region is not affected by sample $\mathrm{pH}$ within the range of 2-7, but is strongly reduced below a $\mathrm{pH}$ of 2 . Data from two independent measurement runs are shown. b The fluorescence intensity of terrestrial HULIS in the coral standard powder is linearly related to the amount of coral powder dissolved, up to a total of $4 \mathrm{mg}$ coral powder in $200 \mu$ l solution

fluorophores in roughly the same proportion to their fluorescence intensity in the initial seawater (Fig. 4d, e).

\section{Downcore correlations between luminescence and HULIS fluorescence}

We refer to variation in fluorescence intensity and luminescence green-to-blue ratios along the coral growth axis going down the core from the most recent to older growth layers simply as 'downcore' measurements. To test whether downcore variation in luminescence green-to-blue ratios covaries with fluorescence intensity, we calculated the correlation coefficients between luminescence greento-blue records and downcore variation in fluorescence intensity at each point across the entire fluorescence EEM spectrum. We consistently found the strongest positive correlations between luminescence green-to-blue ratio and fluorescence intensities in the terrigenous region of the fluorescence EEM spectra (Fig. 5). The correlations were strongest for the coral cores from Kusu (both core sections) and for Port Dickson. For the Kusu core sections, a large region of roughly ex/em 300-470/400-600 shows very high correlations with luminescence green-to-blue with $R$ values $\geq 0.70$ (Fig. 5a, b). The Port Dickson core shows a narrower region of high correlation, with ex/em 310-390/ 410-540 having $R$ values $\geq 0.50$, and longer wavelength combinations giving $R$ values around 0.40 . For all three core sections, the strongest correlations are found at excitation wavelengths between 300 and $375 \mathrm{~nm}$ and emission between 430 and $550 \mathrm{~nm}$ (boxes in Fig. 5a-c), corresponding to areas of the EEM spectrum that are usually identified as terrestrial humic-like fluorescence components (Chen et al. 2003; Coble 2007). In contrast, the Redang and Tioman coral sections do not show the clear peaks of correlation as seen in Kusu and Port Dickson corals. The Redang core does show moderately strong positive correlation, but only at very long wavelengths, with $R$ values of $\geq 0.6$ at ex/em 380-450/470-570. Although this includes the region identified by (Matthews et al. 1996) as the fluorescence peak for commercially available humic acids, the Redang coral does not show correlations between fluorescence intensity and luminescence green-to-blue ratios in any regions of the EEM spectrum that are commonly identified as terrestrial fluorescence components in studies of fluorescent dissolved organic matter in aquatic ecosystems (Chen et al. 2003; Coble 2007). The Tioman core shows the weakest correlations between fluorescence and luminescence green-to-blue of all the core sections. Similar to the Redang coral, the strongest positive correlations in the Tioman core are only found at very long excitation emission wavelengths $(R=0.6)$. There even appears to be a negative correlation at shorter wavelengths in the region canonically associated with marine humic substances, i.e. ex/em 310/390 $(R=-0.6)$.

Kusu, Kusu (drought) and Port Dickson coral sections are plotted as line plots in Fig. 6 show distinct peaks in both luminescence and fluorescence, corresponding to approximately one peak per year (at skeletal growth rates of $\left.1-2 \mathrm{~cm} \mathrm{yr}^{-1}\right)$. The fluorescence values are the averages of the regions with maximum correlations highlighted by red boxes in Fig. 5. The correlation is strongest in the Kusu sections $\left(R^{2}>0.61, p<0.001\right)$. Notably, during the 1997-1998 drought period, both the luminescence and fluorescence showed a much smaller peak than in all other years, consistent with a likely reduction in riverine tDOC fluxes during the drought. The Port Dickson section also shows close correspondence in the peaks and troughs between luminescence and fluorescence data $\left(R^{2}>0.40\right.$, $p<0.001)$. Since the Redang and Tioman corals do not show clear peaks of correlations, no single fluorescence 


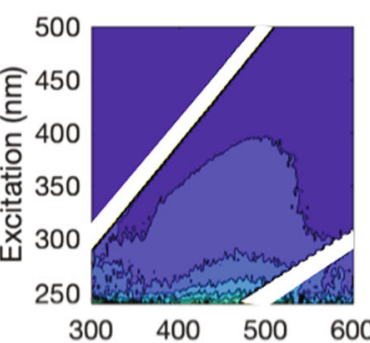

a Peatland river water

$$
\begin{gathered}
\text { peatland water } \\
\text { c Marine } \\
\text { plankton } \\
\text { culture water }
\end{gathered}
$$

\section{peatland water}

$$
\begin{aligned}
& \text { d Kusu } \\
& \text { seawater } \\
& 6 / 19
\end{aligned}
$$

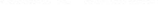

\section{e Kusu seawater time series}
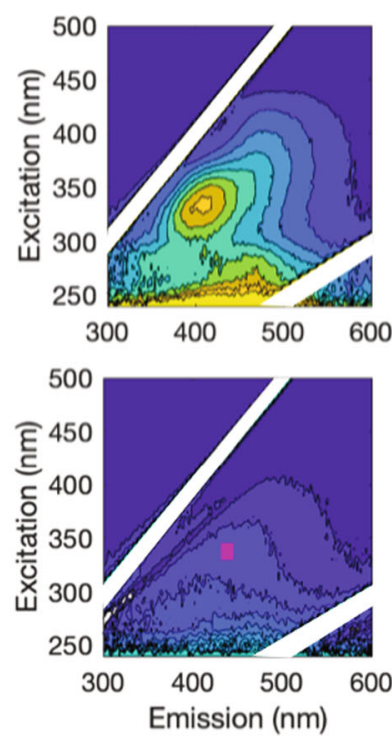

Water sample

\section{Abiogenic aragonite}
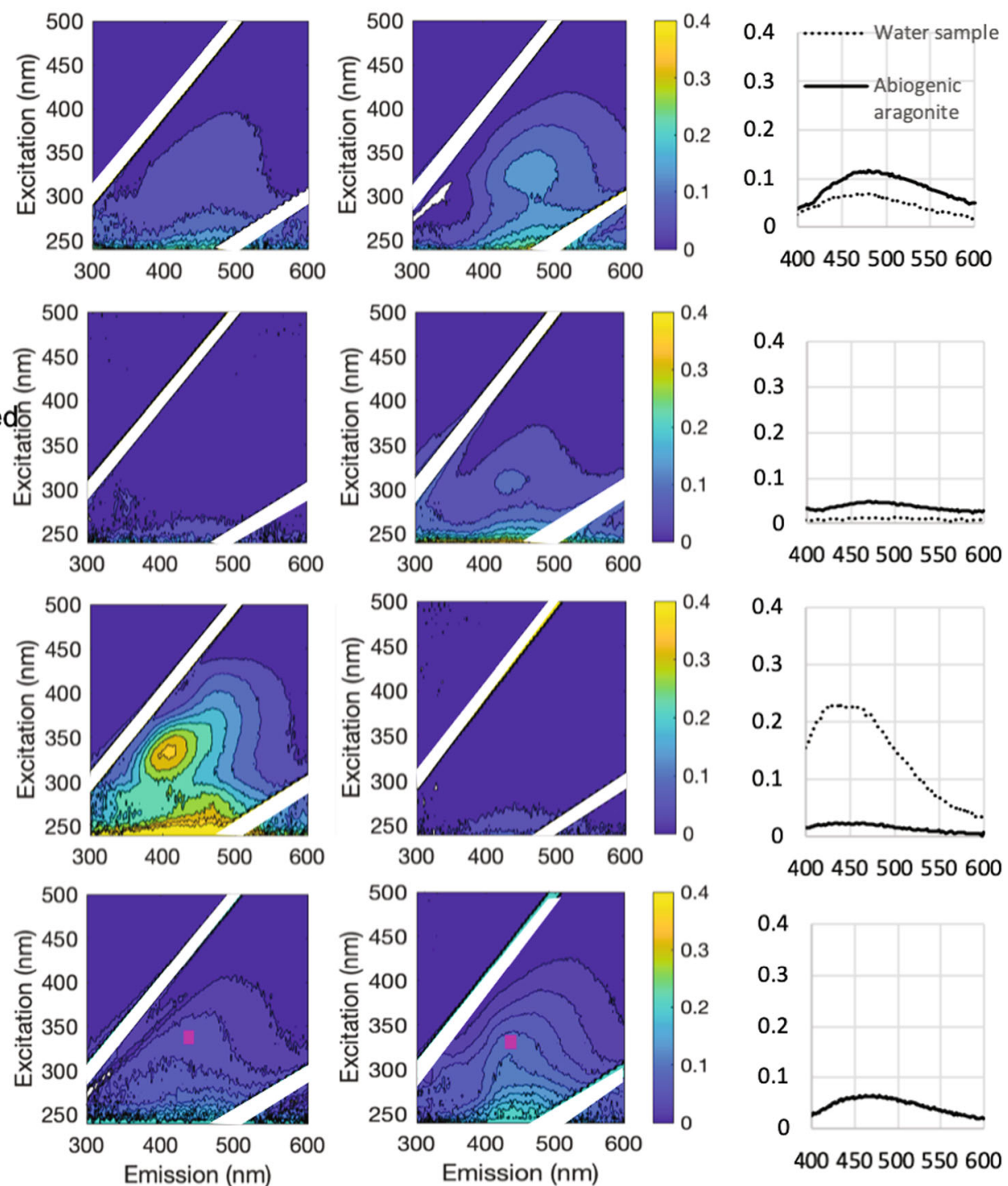

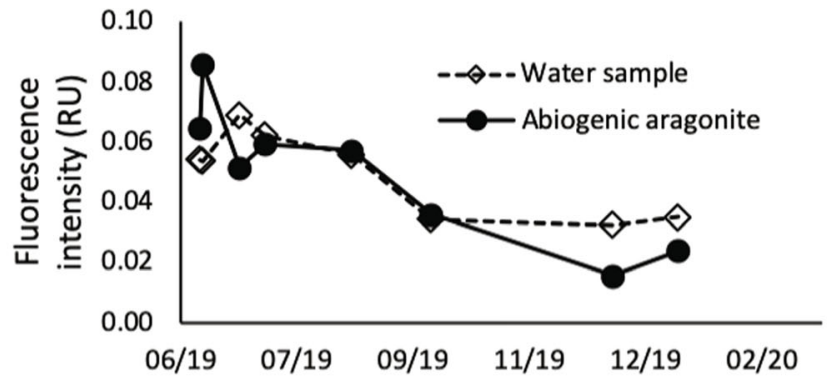

Fig. 4 Fluorescence spectra for water samples and abiogenic aragonite precipitated from those samples for a peatland river water, b photodegraded peatland river water c marine plankton culture water, and $\mathbf{d}$ Kusu seawater. For each sample, the full EEM spectrum is shown as well as a line plot showing the emission spectra at excitation $365 \mathrm{~nm}$. Full fluorescence EEM spectra of the marine plankton experiment in its different stages are shown in Fig. S3 and
S4. In (d), the Kusu seawater and abiogenic aragonite emission spectra at excitation $365 \mathrm{~nm}$ overlie each other, suggesting that aragonite is incorporating terrestrial HULIS in proportion to its concentration in the sea water. e Time series of fluorescence intensity in the HULIS region of ex/em 340-345/434-442 nm for Kusu seawater and abiogenic aragonite precipitated from the water 
Fig. 5 Correlation coefficients between fluorescence and luminescence green-to-blue ratios across the full range of the fluorescence excitation emission matrix (EEM) spectrum for the five coral sections. The colour bar represents the correlation coefficient $(R)$ for each ex/em wavelength combination. Rayleigh scatter bands have been masked. The red boxes show the regions of highest correlation between the luminescence green-to-blue ratios and EEM spectra of the coral sections
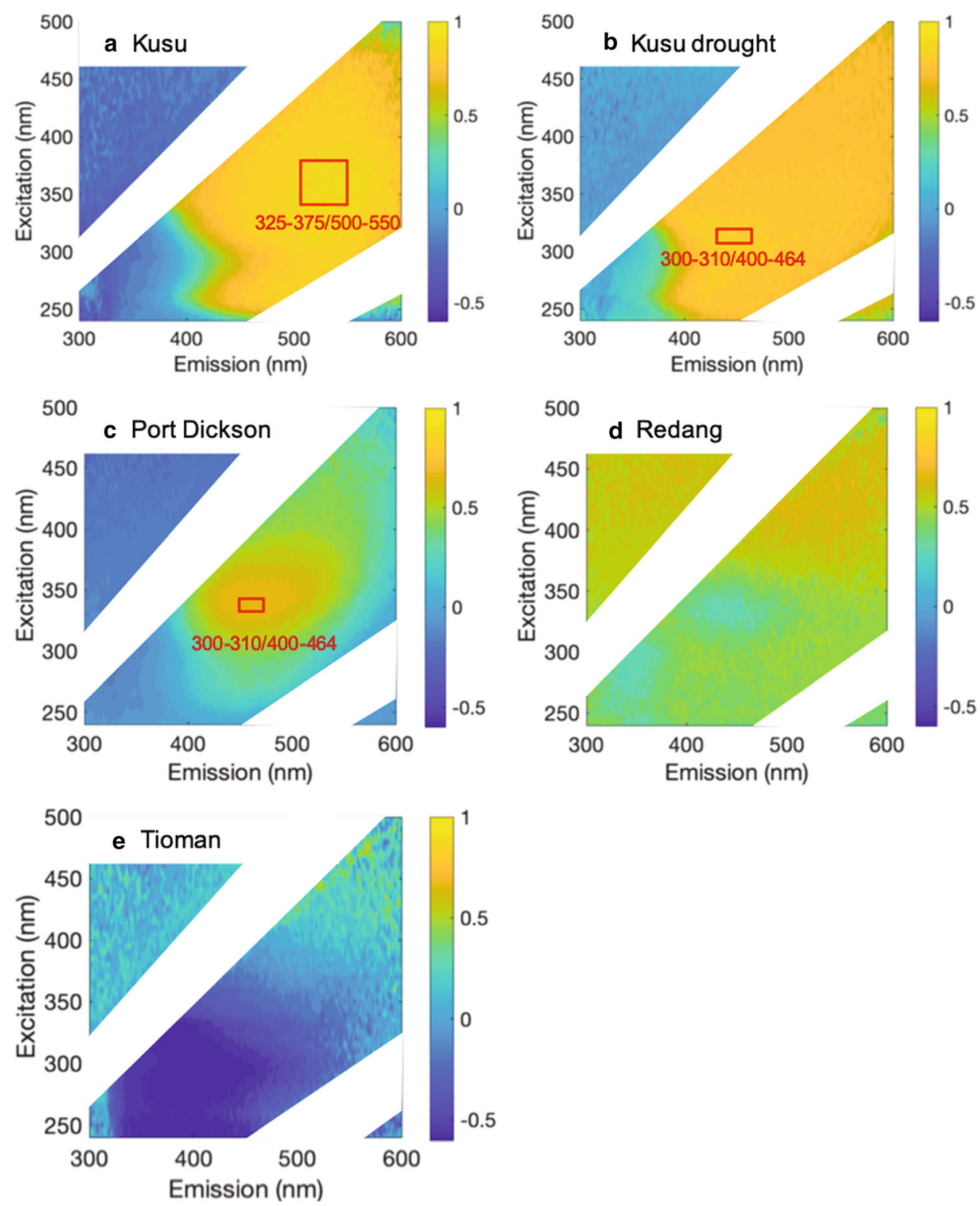

region can be identified and plotted. The luminescence green-to-blue ratios have been plotted in Fig. 6 and show the lowest values and least variability of all five coral sections.

\section{Correlation analysis between coral sections}

Luminescence intensity at blue wavelengths is measured to normalize for aragonite structural variation in the surface scan. Since the solution-based measurements contain dissolved powder, there is no need for the additional normalization. To examine how well the variation in luminescence green-to-blue ratio correlates with fluorescence-based measurements across all core sections, we calculated the "fluorescence green" intensity as the average of the fluorescence emission intensity over the wavelength range of 525-575 $\mathrm{nm}$ at excitation wavelength of $365 \mathrm{~nm}$. When the data from all five coral sections are plotted together, an overall strong linear relationship exists between luminescence green-to-blue and fluorescence green measurements (Fig. 7). Figure 7 clearly shows that data from Tioman and Redang together make up the lowest values in both parameters with the least variation, which may explain the weaker correlations (or lack thereof) found within these two cores.

\section{Discussion}

The four coral cores analysed in this study all showed maximum humic-like substances (HULIS) fluorescence intensity in the spectral region of ex/em 300-350/ 

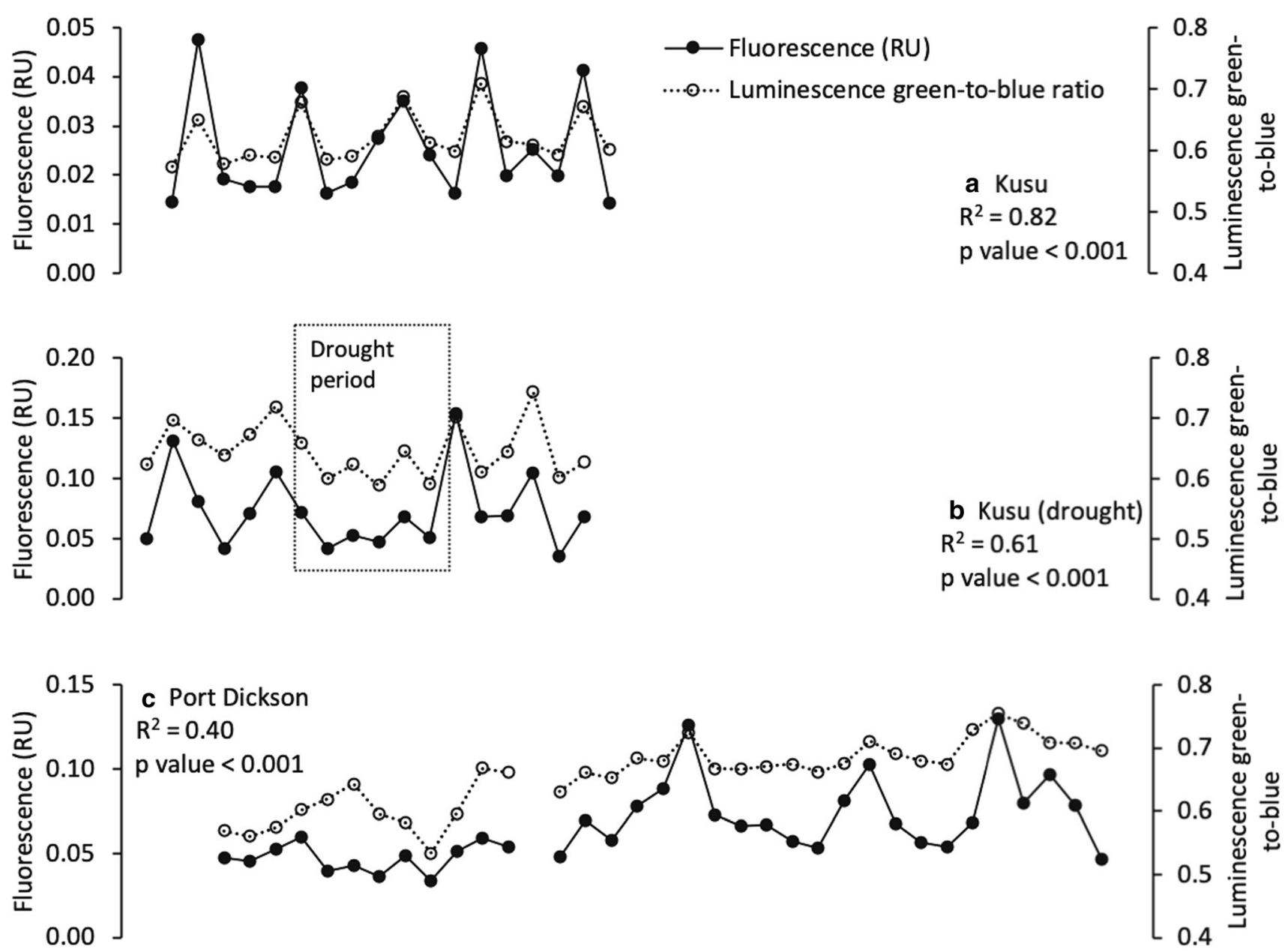

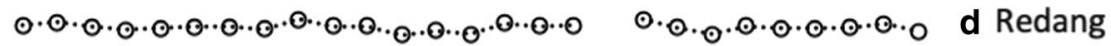

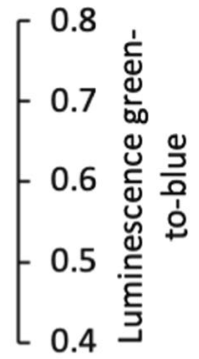

$$
\begin{aligned}
& \begin{array}{c}
\odot . \odot \cdot \odot \cdot \odot^{\circ} \cdot \odot \cdot \odot \cdot \odot \cdot \odot \cdot \odot \cdot \odot \cdot \odot \cdot \odot \cdot \odot \cdot \odot \cdot \odot \cdot \odot \cdot \odot \cdot \odot \cdot \odot \cdot \odot \cdot \odot \cdot \odot \cdot \odot \cdot \odot \cdot \odot \\
\text { Depth (cm) }
\end{array} \\
& \text { e Tioman }
\end{aligned}
$$

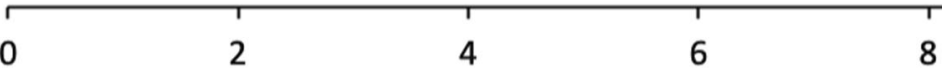

$8 \quad 10$

Fig. 6 Fluorescence and luminescence green-to-blue measurements are plotted against distance along the major growth axis of each coral core section. The fluorescence measurements are the average value of the regions with maximum correlation between luminescence greento-blue and fluorescence excitation emission matrix (EEM) spectra measurements, as indicated with red boxes in Fig. 5 
$400-480 \mathrm{~nm}$. This is in good agreement with both our canonical understanding of the spectral characteristics of terrigenous HULIS in aquatic environments (Coble 2007), and also with the previous coral fluorescence study by (Matthews et al. 1996). The linear concentration dependence of the HULIS fluorescence intensity and the lack of pH sensitivity between $\mathrm{pH} 2$ and 7 are both consistent with prior studies of terrestrial HULIS fluorescence in water samples, in abiogenic calcite (Pearson et al. 2020) and in coral skeleton (Matthews et al. 1996). Unlike Matthews et al. (1996), the samples in this study were dissolved and measured directly without first extracting the organic matter. This allows HULIS fluorescence measurements in much smaller subsamples of coral skeleton $(2-2.5 \mathrm{mg}$ compared to $1000-20,000 \mathrm{mg}$ ) and allows a temporal resolution of 2-3 months, depending on the coral's linear extension rate. The whole-sample dissolution method described here allows all organic substances in the skeleton to be measured together, whereas extraction-based approaches cannot purify all organic matter with $100 \%$ efficiency, meaning that some signals might be lost. Moreover, extractions also subject the organic matter to more extreme changes in solution $\mathrm{pH}$.

Pearson et al. (2020) examined the incorporation of dissolved organic matter (DOM) from groundwater into stalagmites in caves, using a similar technique to ours: they precipitated abiogenic $\mathrm{CaCO}_{3}$ from water samples that were amended with peatland DOM, and measured fluorescence EEM spectra after dissolving the $\mathrm{CaCO}_{3}$ samples. Their findings with calcite precipitation are similar to our results with aragonite - the fluorescence signal in the precipitated $\mathrm{CaCO}_{3}$ was dominated by the humic-like Peak $\mathrm{C}$ (ex/em 330-350/420-480 nm (Coble 1996). The concentration of peatland-derived DOM in the precipitated calcite was also proportional to the concentration in the initial solution, and they concluded that peatland DOM is preferentially incorporated into the calcite. Although they found fluorescence in the Peak A region (ex/em 250-260/
380-480 nm) in the water samples, Peak A was not found in the precipitated calcite. Peak A is also thought to be sourced from humic-like substances in bulk seawater (Coble 1996). We similarly find a peak at ex/em 250-300/ $325-375 \mathrm{~nm}$ to be present in some samples of peatland river water, the photodegraded peatland river water, the marine plankton culture water and in the Kusu sea water, but it is not present in aragonite precipitated from these samples. However, the peak at ex/em 250-500/ 325-375 $\mathrm{nm}$ was seen in some of the coral samples measured in this study possible reflecting the deliberate incorporatioon of organic matrix molecules such as proteins during the coral calcification process (Coble 1996).

DeCarlo et al. (2018) used abiogenic precipitation experiments to show that coral skeletons must contain organic matter other than coral-polyp-derived skeletal organic matrix. Tambutté et al. (2012) showed that dissolved organic molecules such as calcein can diffuse passively to the coral calcification site by a paracellular pathway, i.e. through intercellular channels in the coral tissue. This suggests that a chemically diverse range of natural dissolved organic matter could potentially reach the calcification site and become incorporated in the skeleton, highlighting the value of techniques such as EEM spectroscopy that can distinguish different organic matter types. Our abiogenic precipitation experiments with different types of organic matter suggest that compounds such as peatland-derived HULIS are preferentially incorporated over organic fluorophores produced by plankton in the marine environment. Moreover, the abiogenic experiments with Kusu water in this study yielded EEM spectra and HULIS fluorescence intensities similar to spectra observed in the coral skeletons, and in proportion to the HULIS fluorescence intensity in the water. This suggests that corals probably incorporate terrestrial HULIS passively when these fluorophores associate with the growing $\mathrm{CaCO}_{3}$ crystals.
Fig. 7 Luminescence green-toblue measurements show a strong relationship to fluorescence green measurements across all coral core sections

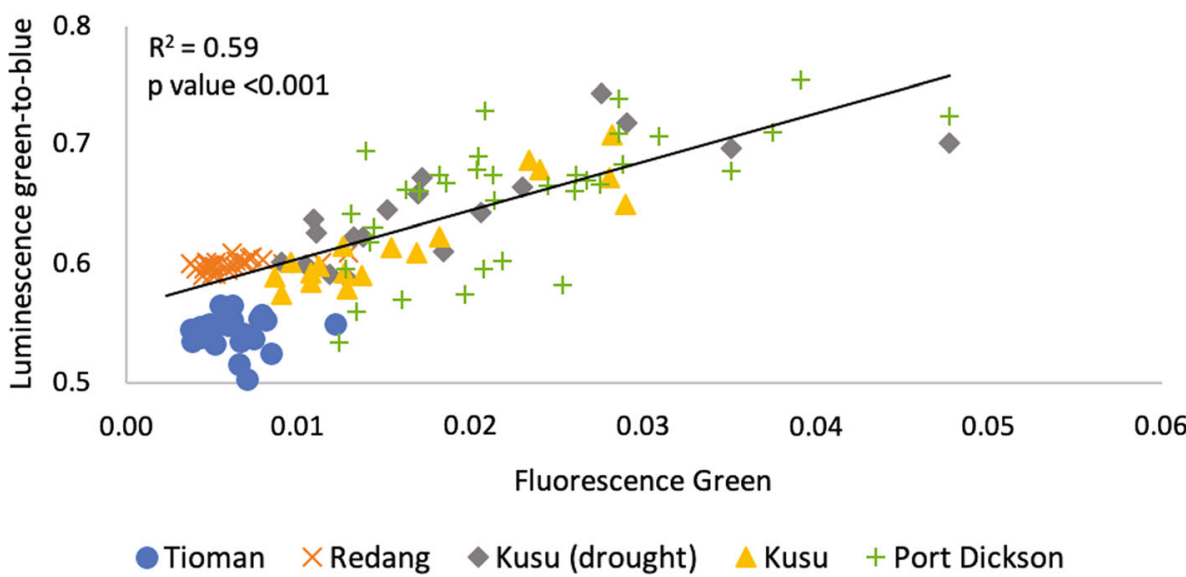

Tioman $\times$ Redang Kusu (drought) Kusu + Port Dickson 
Early investigations of coral luminescence led to debate about the degree to which the coral aragonite structure contributes to the luminescence signal (Barnes and Taylor 2005). The use of luminescence green-to-blue ratios rather than absolute luminescence intensity was proposed specifically to avoid artifacts from structural variation, because aragonite emits light at shorter wavelengths than HULIS (Grove et al. 2010). By developing a technique to measure terrestrial HULIS fluorescence in small coral samples in solution, our study shows clearly that the incorporation of terrestrial HULIS is the main driver of luminescence green-to-blue variation when the luminescence green-to-blue ratios are high (in our cores, $>0.6$ ) and the variability is more than around \pm 0.05 . This condition holds true for two of our four coral sites. Singapore and Port Dickson are located close to Sumatra and Borneo and likely experience overall higher concentrations of peatland-derived humic acid-rich tDOC, with seasonal variation caused by monsoonal changes in precipitation and ocean current direction. Tropical peatlands are the most significant source of terrigenous dissolved organic carbon (tDOC) to Southeast Asian coastal waters (Alkhatib et al. 2007; Baum et al. 2007; Moore et al. 2011). Tioman and Redang are farther away from peatland influence, consistent with the lower green-to-blue ratios and lower HULIS fluorescence intensity in these cores.

Tudhope et al. (1996) reported intense luminescent bands in corals collected from Oman, although this was not quantified as the green-to-blue ratio. The lack of a reasonable terrigenous source of organic compounds lead them to speculate that marine humic substances might become incorporated in coral skeletons. Matthews et al. (1996) suggested that marine humic matter was present in Thai corals based on the presence of a protein peak (ex/em 280/350 nm) and the absence of a HULIS peak. Marine humic substances have been identified in seawater using fluorescence EEM spectroscopy as the peak at ex/em 310/390 nm (Coble 1996; Cory and McKnight 2005; Yamashita et al. 2008; Fellman et al. 2010). A marine humic peak may be produced directly by phytoplankton (Castillo et al. 2010; Kinsey et al. 2018) or by bacterial reprocessing of phytoplankton-derived organic matter (Kinsey et al. 2018). Zhou et al. (2019) identified a component in the marine humic wavelength range in Sarawak (Borneo), but concluded based on its mixing behaviour from peat-draining rivers to marine waters and correlations with their other components that it was terrestrial in origin. This has also been suggested by other studies (Stedmon et al. 2003; Murphy et al. 2008; Yamashita et al. 2011; Harun et al. 2016). Our abiogenic experiments also show clearly that fluorescent DOM produced by marine plankton is not strongly incorporated into aragonite. Moreover, none of our coral cores show clear fluorescence variation in the marine humic peak region, not even the corals from Tioman and Redang, where the terrestrial organic matter input was lower. We therefore conclude that corals do not seem to strongly incorporate marine humic substances, and that the presence of dissolved fluorophores of marine origin probably does not contribute to luminescence green-to-blue variation in coral cores. We speculate that even small, oceanic islands might provide a sufficiently significant, local source of terrestrial DOM from vegetation that coral colonies fringing such islands might display seasonal luminescent banding depending on the local rainfall seasonality and the residence time of freshwater runoff on the reef.

Our results show instead that large variations in the luminescence green-to-blue ratios both within and between corals are largely driven by variations in terrestrial HULIS concentration in the coral skeleton. Terrigenous fractions of dissolved organic matter are reported to show conservative mixing behaviour across peatland-draining estuaries in Southeast Asia (Alkhatib et al. 2007; Baum et al. 2007; Rixen et al. 2008; Martin et al. 2018; Zhou et al. 2019). Since HULIS fluorescence is a good tracer for tDOC concentrations in coastal waters, and often shows conservative mixing behaviour within shelf seas (Stedmon et al. 2003; Yamashita et al. 2011; Painter et al. 2018), coral cores may hold the potential to reconstruct past tDOC concentrations in locations where historical time series of biogeochemical parameters are lacking. Further experiments are required to establish relationships between terrestrial HULIS fluorescence and luminescence green-toblue ratios in coral cores with estimates of tDOC concentration in sea water, and to determine whether "vital effects', such as growth rates and physiology, cause additional variation between coral specimens.

Acknowledgements We are grateful to the coral coring teams responsible for collecting the coral samples and for sample permits from the Department of Marine Park Malaysia (JTLM620-2/112(9)), Department of Fisheries Malaysia (Prk.ML.S.04/32/3Jld.7(9)) and Singapore National Parks (NP/RP11-016b). We thank Moritz Müller and his team for collecting and filtering Maludam water. We are grateful to Tong Kai Ting for collecting Kusu seawater samples and conducting some of the abiogenic aragonite precipitation experiments; Avneet Kaur and Adriana Lopes dos Santos for help with plankton culturing, and Yongli Zhou for help with the peatland river photodegradation experiment. We thank Hrothgar for his assistance with the code used to produce the EEM spectra and the code used to perform correlation analysis and René Dommain for providing the base map for Fig. 1. We also thank the editors and two anonymous reviewers for their time and helpful comments. Funding was provided by an Academic Research Fund Tier 1 grant from the Singapore Ministry of Education to P.M. (Grant RG123/18), by the National Research Foundation Singapore through an International Collaborative Fellowship for the Commonwealth to N.K. (Grant NRF-CSCICFC2017-01), by the National Research Foundation Singapore under the Marine Science Research and Development Programme to J.T.I.T. 
and N.F.G. (Project MSRDP-03), and from the Ministry of Education Malaysia through Grant FRGS/2/2013/STWN04/UMT/03/1 to J.N.L.

\section{Compliance with ethical standards}

Conflict of interest On behalf of all authors, the corresponding author states that there is no conflict of interest.

Open Access This article is licensed under a Creative Commons Attribution 4.0 International License, which permits use, sharing, adaptation, distribution and reproduction in any medium or format, as long as you give appropriate credit to the original author(s) and the source, provide a link to the Creative Commons licence, and indicate if changes were made. The images or other third party material in this article are included in the article's Creative Commons licence, unless indicated otherwise in a credit line to the material. If material is not included in the article's Creative Commons licence and your intended use is not permitted by statutory regulation or exceeds the permitted use, you will need to obtain permission directly from the copyright holder. To view a copy of this licence, visit http://creativecommons. org/licenses/by/4.0/.

\section{References}

Aksnes DL, Dupont N, Staby A, Fiksen Ø, Kaartvedt S, Aure J (2009) Coastal water darkening and implications for mesopelagic regime shifts in Norwegian fjords. Marine Ecology Progress Series 387:39-49

Alkhatib M, Jennerjahn TC, Samiaji J (2007) Biogeochemistry of the Dumai River estuary, Sumatra, Indonesia, a tropical black-water river. Limnology and Oceanography 52:2410-2417

Barnes DJ, Taylor RB (2005) On the nature and causes of luminescent lines and bands in coral skeletons: II. Contribution of skeletal crystals. Journal of Experimental Marine Biology and Ecology 322:135-142

Baum A, Rixen T, Samiaji J (2007) Relevance of peat draining rivers in central Sumatra for the riverine input of dissolved organic carbon into the ocean. Estuarine, Coastal and Shelf Science 73:563-570

Bianchi TS (2011) The role of terrestrially derived organic carbon in the coastal ocean: a changing paradigm and the priming effect. PNAS 108:19473-19481

Boto K, Isdale P (1985) Fluorescent bands in massive corals result from terrestrial fulvic acid inputs to nearshore zone. Nature 315:396-397

Cai W-J (2011) Estuarine and Coastal Ocean Carbon Paradox: CO2 Sinks or Sites of Terrestrial Carbon Incineration? Annual Review of Marine Science 3:123-145

Castillo CR, Sarmento H, Álvarez-Salgado XA, Gasol JM, Marraséa C (2010) Production of chromophoric dissolved organic matter by marine phytoplankton. Limnology and Oceanography 55:446-454

Chen W, Westerhoff P, Leenheer JA, Booksh K (2003) Fluorescence Excitation - Emission Matrix Regional Integration to Quantify Spectra for Dissolved Organic Matter. Environ Sci Technol 37:5701-5710

Coble PG (1996) Characterization of marine and terrestrial DOM in seawater using excitation-emission matrix spectroscopy. Marine Chemistry 51:325-346

Coble PG (2007) Marine Optical Biogeochemistry: The Chemistry of Ocean Color. Chem Rev 107:402-418

Cory RM, Kling GW (2018) Interactions between sunlight and microorganisms influence dissolved organic matter degradation along the aquatic continuum. Limnology and Oceanography Letters 3:102-116

Cory RM, McKnight DM (2005) Fluorescence Spectroscopy Reveals Ubiquitous Presence of Oxidized and Reduced Quinones in Dissolved Organic Matter. Environ Sci Technol 39:8142-8149

DeCarlo TM, Ren H, Farfan GA (2018) The Origin and Role of Organic Matrix in Coral Calcification: Insights From Comparing Coral Skeleton and Abiogenic Aragonite. Front Mar Sci 5

Dommain R, Couwenberg J, Glaser PH, Joosten H, Suryadiputra INN (2014) Carbon storage and release in Indonesian peatlands since the last deglaciation. Quaternary Science Reviews 97:1-32

Druffel ERM (1997) Geochemistry of corals: Proxies of past ocean chemistry, ocean circulation, and climate. PNAS 94:8354-8361

Edmunds PJ, Tsounis G, Boulon R, Bramanti L (2018) Long-term variation in light intensity on a coral reef. Coral Reefs 37:955-965

Evans CD, Monteith DT, Cooper DM (2005) Long-term increases in surface water dissolved organic carbon: Observations, possible causes and environmental impacts. Environmental Pollution 137:55-71

Fellman JB, Hood E, Spencer RGM (2010) Fluorescence spectroscopy opens new windows into dissolved organic matter dynamics in freshwater ecosystems: A review. Limnology and Oceanography 55:2452-2462

Foden J, Sivyer DB, Mills DK, Devlin MJ (2008) Spatial and temporal distribution of chromophoric dissolved organic matter (CDOM) fluorescence and its contribution to light attenuation in UK waterbodies. Estuarine, Coastal and Shelf Science 79:707-717

Gaetani GA, Cohen AL (2006) Element partitioning during precipitation of aragonite from seawater: A framework for understanding paleoproxies. Geochimica et Cosmochimica Acta 70:4617-4634

Gandois L, Hoyt AM, Mounier S, Roux GL, Harvey CF, Claustres A, Nuriman M, Anshari G (2020) From canals to the coast: dissolved organic matter and trace metal composition in rivers draining degraded tropical peatlands in Indonesia. Biogeosciences 17:1897-1909

Gordon AL, Susanto RD, Vranes K (2003) Cool Indonesian throughflow as a consequence of restricted surface layer flow. Nature 425:824-828

Green SA, Blough NV (1994) Optical absorption and fluorescence properties of chromophoric dissolved organic matter in natural waters. Limnology and Oceanography 39:1903-1916

Grove CA, Nagtegaal R, Zinke J, Scheufen T, Koster B, Kasper S, McCulloch MT, Bergh G van den, Brummer GJA (2010) River runoff reconstructions from novel spectral luminescence scanning of massive coral skeletons. 579-591

Guillard RRL, Ryther JH (1962) Studies of Marine Planktonic Diatoms: I. Cyclotella Nana Hustedt, and Detonula Confervacea (cleve) Gran. Can J Microbiol 8:229-239

Harun S, Baker A, Bradley C, Pinay G (2016) Spatial and seasonal variations in the composition of dissolved organic matter in a tropical catchment: the Lower Kinabatangan River, Sabah, Malaysia. Environmental Science: Processes \& Impacts $18: 137-150$

Hedges JI, Cowie GL, Ertel JR, James Barbour R, Hatcher PG (1985) Degradation of carbohydrates and lignins in buried woods. Geochimica et Cosmochimica Acta 49:701-711

Hernes PJ, Benner R (2003) Photochemical and microbial degradation of dissolved lignin phenols: Implications for the fate of terrigenous dissolved organic matter in marine environments. Journal of Geophysical Research: Oceans 108:

Isdale P (1984) Fluorescent bands in massive corals record centuries of coastal rainfall. Nature 310:578-579 
Isdale PJ, Stewart BJ, Tickle KS, Lough JM (1998) Palaeohydrological variation in a tropical river catchment: a reconstruction using fluorescent bands in corals of the Great Barrier Reef, Australia. The Holocene 8:1-8

Isdale PJ, Stewart BJ, Tickle KS, Lough JM (2016) Palaeohydrological variation in a tropical river catchment: a reconstruction using fluorescent bands in corals of the Great Barrier Reef. The Holocene, Australia

Kinsey JD, Corradino G, Ziervogel K, Schnetzer A, Osburn CL (2018) Formation of Chromophoric Dissolved Organic Matter by Bacterial Degradation of Phytoplankton-Derived Aggregates. Front Mar Sci 4

Lau KM, Yang S (1997) Climatology and interannual variability of the southeast asian summer monsoon. Adv Atmos Sci 14:141-162

Lawaetz AJ, Stedmon CA (2009) Fluorescence Intensity Calibration Using the Raman Scatter Peak of Water. Appl Spectrosc, AS 63:936-940

Lough J, Barnes D, McAllister F (2002) Luminescent lines in corals from the Great Barrier Reef provide spatial and temporal records of reefs affected by land runoff. Coral Reefs 21:333-343

Lough JM (2007) Tropical river flow and rainfall reconstructions from coral luminescence: Great Barrier Reef, Australia. Paleoceanography 22

Lough JM (2010) Climate records from corals. WIREs Climate Change 1:318-331

Maren DS van, Gerritsen H (2012) Residual flow and tidal asymmetry in the Singapore Strait, with implications for resuspension and residual transport of sediment. Journal of Geophysical Research: Oceans 117

Martin P, Cherukuru N, Tan ASY, Sanwlani N, Mujahid A, Müller M (2018) Distribution and cycling of terrigenous dissolved organic carbon in peatland-draining rivers and coastal waters of Sarawak, Borneo. Biogeosciences 15:6847-6865

Matthews BJH, Jones AC, Theodorou NK, Tudhope AW (1996) Excitation-emission-matrix fluorescence spectroscopy applied to humic acid bands in coral reefs. Marine Chemistry 55:317-332

Miettinen J, Shi C, Liew SC (2016) Land cover distribution in the peatlands of Peninsular Malaysia, Sumatra and Borneo in 2015 with changes since 1990. Global Ecology and Conservation 6:67-78

Monteith DT, Stoddard JL, Evans CD, de Wit HA, Forsius M, Høgåsen T, Wilander A, Skjelkvåle BL, Jeffries DS, Vuorenmaa J, Keller B, Kopácek J, Vesely J (2007) Dissolved organic carbon trends resulting from changes in atmospheric deposition chemistry. Nature 450:537-540

Moore S, Evans CD, Page SE, Garnett MH, Jones TG, Freeman C, Hooijer A, Wiltshire AJ, Limin SH, Gauci V (2013) Deep instability of deforested tropical peatlands revealed by fluvial organic carbon fluxes. Nature 493:660-663

Moore S, Gauci V, Evans CD, Page SE (2011) Fluvial organic carbon losses from a Bornean blackwater river. Biogeosciences 8:901-909

Moran MA, Sheldon WM, Zepp RG (2000) Carbon loss and optical property changes during long-term photochemical and biological degradation of estuarine dissolved organic matter. Limnology and Oceanography 45:1254-1264

Müller D, Warneke T, Rixen T, Müller M, Mujahid A, Bange HW, Notholt J (2016) Fate of terrestrial organic carbon and associated $\mathrm{CO} 2$ and $\mathrm{CO}$ emissions from two Southeast Asian estuaries. Biogeosciences (BG) 13:691-705

Murphy KR, Stedmon AC, Graeber D, Bro R (2013) Fluorescence spectroscopy and multi-way techniques. PARAFAC Analytical Methods 5:6557-6566

Murphy KR, Stedmon CA, Waite TD, Ruiz GM (2008) Distinguishing between terrestrial and autochthonous organic matter sources in marine environments using fluorescence spectroscopy. Marine Chemistry 108:40-58

Nagtegaal R, Grove CA, Kasper S, Zinke J, Boer W, Brummer G-JA (2012) Spectral luminescence and geochemistry of coral aragonite: Effects of whole-core treatment. Chemical Geology 318-319:6-15

Osburn CL, Boyd TJ, Montgomery MT, Bianchi TS, Coffin RB, Paerl HW (2016) Optical Proxies for Terrestrial Dissolved Organic Matter in Estuaries and Coastal Waters. Front Mar Sci 2

Osburn CL, Kinsey JD, Bianchi TS, Shields MR (2019) Formation of planktonic chromophoric dissolved organic matter in the ocean. Marine Chemistry 209:1-13

Page SE, Rieley JO, Banks CJ (2011) Global and regional importance of the tropical peatland carbon pool. Global Change Biology $17: 798-818$

Paillard D, Labeyrie L, Yiou P (1996) Macintosh Program performs time-series analysis. Eos, Transactions American Geophysical Union 77:379

Painter SC, Lapworth DJ, Woodward EMS, Kroeger S, Evans CD, Mayor DJ, Sanders RJ (2018) Terrestrial dissolved organic matter distribution in the North Sea. Science of The Total Environment 630:630-647

Pearson AR, Hartland A, Frisia S, Fox BRS (2020) Formation of calcite in the presence of dissolved organic matter: Partitioning, fabrics and fluorescence. Chemical Geology 539:119492

Regnier P, Friedlingstein P, Ciais P, Mackenzie FT, Gruber N, Janssens IA, Laruelle GG, Lauerwald R, Luyssaert S, Andersson AJ, Arndt S, Arnosti C, Borges AV, Dale AW, Gallego-Sala A, Goddéris Y, Goossens N, Hartmann J, Heinze C, Ilyina T, Joos F, LaRowe DE, Leifeld J, Meysman FJR, Munhoven G, Raymond PA, Spahni R, Suntharalingam P, Thullner M (2013) Anthropogenic perturbation of the carbon fluxes from land to ocean. Nature Geosci 6:597-607

Rixen T, Baum A, Pohlmann T, Balzer W, Samiaji J, Jose C (2008) The Siak, a tropical black water river in central Sumatra on the verge of anoxia. Biogeochemistry 90:129-140

Rizal S, Damm P, Wahid MA, Sundermann J, Ilhamsyah Y, Iskandar T, Muhammad (2012) General Circulation in the Malacca Strait and Andaman Sea: A Numerical Model Study. American Journal of Environmental Sciences 8:479-488

Stedmon CA, Markager S, Bro R (2003) Tracing dissolved organic matter in aquatic environments using a new approach to fluorescence spectroscopy. Marine Chemistry 82:239-254

Susic M, Boto K, Isdale P (1991) Fluorescent humic acid bands in coral skeletons originate from terrestrial runoff. Marine Chemistry 33:91-104

Susic M, Boto KG (1989) High-performance liquid chromatographic determination of humic acid in environmental samples at the nanogram level using fluorescence detection. Journal of Chromatography A 482:175-187

Tambutté E, Tambutté S, Segonds N, Zoccola D, Venn A, Erez J, Allemand D (2012) Calcein labelling and electrophysiology: insights on coral tissue permeability and calcification. Proceedings of the Royal Society B: Biological Sciences 279:19-27

Tanzil JTI, Goodkin NF, Sin TM, Chen ML, Fabbro GN, Boyle EA, Lee AC, Toh KB (2019) Multi-colony coral skeletal Ba/Ca from Singapore's turbid urban reefs: Relationship with contemporaneous in situ seawater parameters. Geochimica et Cosmochimica Acta 250:191-208

Tanzil JTI, Lee JN, Brown BE, Quax R, Kaandorp JA, Lough JM, Todd PA (2016) Luminescence and density banding patterns in massive Porites corals around the Thai-Malay Peninsula, Southeast Asia. Limnology and Oceanography 61:2003-2026

Tedetti M, Cuet P, Guigue C, Goutx M (2011) Characterization of dissolved organic matter in a coral reef ecosystem subjected to anthropogenic pressures (La Réunion Island, Indian Ocean) 
using multi-dimensional fluorescence spectroscopy. Science of The Total Environment 409:2198-2210

Thurman E, Malcolm R (1981) Isolation of natural organic matter by resin absorption. Environ Sci Technol 15(4):463-466

Tudhope AW, Lea DW, Shimmield GB, Chilcott CP, Head S (1996) Monsoon Climate and Arabian Sea Coastal Upwelling Recorded in Massive Corals from Southern Oman. PALAIOS 11:347-361

Walker SA, Amon RMW, Stedmon C, Duan S, Louchouarn P (2009) The use of PARAFAC modeling to trace terrestrial dissolved organic matter and fingerprint water masses in coastal Canadian Arctic surface waters. Journal of Geophysical Research: Biogeosciences 114

Wit F, Rixen T, Baum A, Pranowo WS, Hutahaean AA (2018) The Invisible Carbon Footprint as a hidden impact of peatland degradation inducing marine carbonate dissolution in Sumatra, Indonesia. Scientific Reports 8:1-10

Wong CL, Venneker R, Uhlenbrook S, Jamil ABM, Zhou Y (2009) Variability of rainfall in Peninsular Malaysia. Hydrology and Earth System Sciences Discussions 6:5471-5503

Yamashita Y, Jaffé R, Maie N, Tanoue E (2008) Assessing the dynamics of dissolved organic matter (DOM) in coastal environments by excitation emission matrix fluorescence and parallel factor analysis (EEM-PARAFAC). Limnology and Oceanography 53:1900-1908

Yamashita Y, Panton A, Mahaffey C, Jaffé R (2011) Assessing the spatial and temporal variability of dissolved organic matter in Liverpool Bay using excitation-emission matrix fluorescence and parallel factor analysis. Ocean Dynamics 61:569-579

Yule CM, Lim YY, Lim TY (2018) Recycling of phenolic compounds in Borneo's tropical peat swamp forests. Carbon Balance and Management 13:3

Zhou Y, Martin P, Müller M (2019) Composition and cycling of dissolved organic matter from tropical peatlands of coastal Sarawak, Borneo, revealed by fluorescence spectroscopy and parallel factor analysis. Biogeosciences 16:2733-2749

Zigah PK, McNichol AP, Xu L, Johnson C, Santinelli C, Karl DM, Repeta DJ (2017) Allochthonous sources and dynamic cycling of ocean dissolved organic carbon revealed by carbon isotopes. Geophysical Research Letters 44:2407-2415

Publisher's Note Springer Nature remains neutral with regard to jurisdictional claims in published maps and institutional affiliations. 